\title{
PERFORMANCE OF THE PINEAPPLE SWEET ORANGE ON DIFFERENT ROOTSTOCKS
}

\author{
COMPORTAMENTO DA LARANJEIRA 'PINEAPPLE’ EM DIFERENTES PORTA- \\ ENXERTOS
}

\author{
Carlos Roberto MARTINS ${ }^{1}$; Hélio Wilson Lemos de CARVALHO²; \\ Adenir Vieira TEODORO²; Inácio de BARROS ${ }^{3}$; Luciana Marques de CARVALHO²; \\ Walter dos Santos SOARES FILHO ${ }^{4}$; Orlando Sampaio PASSOS ${ }^{4}$ \\ 1. Embrapa Clima Temperado, Pelotas, RS, carlos.r.martins@embrapa.br; 2. Embrapa Tabuleiros Costeiros, Aracaju, SE, 3. Embrapa \\ Gado de Leite, Juiz de Fora, MG, Brasil; 4. Embrapa Mandioca e Fruticultura, Cruz das Almas, BA.
}

\begin{abstract}
This study aimed at evaluating the agronomical performance of 'Pineapple' sweet orange grafted on ten rootstocks, in 2011-2017 harvests, so as to recommend the best combinations to be commercially explored in citrus growing regions in Bahia and Sergipe states, Brazil. An experiment was installed to test ten rootstock for 'pineapple' sweet orange: 'Santa Cruz' Rangpur lime, 'Red Rough' Lemon, 'Orlando' Tangelo, 'Sunki Tropical' Mandarin, 'Swingle' citrumelo, the citrandarins 'Indio' and 'Riverside' and the hybrids HTR-051, LVKxLCR-010 and TSKxCTTR-002. The trial was installed in 2008 in the municipality of Umbauba in Sergipe. The experimental design was complete randomized blocks with four replications and two plants per plot. Plant spacing was $6 \times 4 \mathrm{~m}$ which corresponds to 416 plants per hectare and the orchard was rainfed and followed conventional management. The following agronomical parameters were evaluated: vegetative growth, drought tolerance, yield and physico-chemical quality of fruits as well as the abundance of phytophagous mites. Both hybrids LVK x LCR - 010 and TSKC x CTTR-002 and the 'Santa Cruz' rangpur lime bestowed higher tolerance to the dry period on the 'Pineapple' orange tree, by comparison with higher water deficit susceptibility conferred by the 'Orlando' tangelo and the 'Swingle' citrumelo. Rootstocks HTR051, 'Riverside' citrandarin, 'Swingle' citrumelo and TSKC x CTTR-02 induced plants to remain small and, thus, showed aptitude for culture densification. Cumulative yield of the 'Pineapple' orange was higher on rootstocks 'Red Rough' lemon and 'Santa Cruz' Rangpur lime, the hybrid LVK x LCR-010 and 'Sunki Tropical'. Yield efficiency was not influenced by the rootstocks. Physico-chemical quality of fruits of 'Pineapple' orange is affected by the rootstocks and meets the requirements of juice industries. Regarding plant resistance, the rootstocks did not influence the population density of mites P. oleivora, E. banksi and T. mexicanus on 'Pineapple' oranges. Results show that both rootstocks 'Red Rough' lemon and 'Santa Cruz' rangpur lime conferred high regularity to 'Pineapple' orange trees in citrus growing regions in Bahia and Sergipe states.
\end{abstract}

KEYWORDS: Citrus. Yield Efficiency. Phytophagous Mites. Planting Density.

\section{INTRODUCTION}

Sweet orange [Citrus sinensis (L.) Osbeck] is one of the most consumed fruits in the world, both as fresh fruits and as juice. In Brazil, 18 million tons oranges are harvested annually, representing $35 \%$ and $56 \%$ of fruit production and juice production worldwide, respectively (CURTOLO, et al., 2017). Brazil participation in the world's market is about 85\% (AZEVEDO et al., 2015) anda the northeastern region accounts for $10 \%$ of the country's production and is its second largest growing region, with groves stretching over142,826 ha and producing 1,948,043 tons fruits, for instance, the mean yield is 13.3 t.ha $^{-1}$ (IBGE, 2017).
Most citrus orchards in Brazil's northeastern region are located in the north of Bahia (BA) and in the south of Sergipe (SE) on a strip of the geoenvironmental unit named Coastal Tablelands (SOUZA; SOUZA; LEDO, 2007; MELO FILHO et al., 2009). Orchards in this region are mostly formed by the combination of the 'Pera' sweet orange, clone CNPMF-D6 (RODRIGUES et al., 2016) grafted on the 'Rangpur' lime (C. limonia Osbeck) lemon (PRUDENTE; SILVA; CUNHA SOBRINHO, 2004; CUNHA SOBRINHO et al., 2013; MARTINS; TEODORO; CARVALHO, 2016), whose production is intended for the juice processing industry. In this region, the diversification of scion and rootstock cultivars has been the focus of several studies as a response to 
economic problems the sector faces, including the phytosanitary vulnerability monocultures (RODRIGUES et al., 2016; CARVALHO et al., 2016a; CARVALHO et al., 2016b; MARTINS; TEODORO; CARVALHO, 2016; SILVA et al., 2017), the demand for production distribution as the result of manpower shortage for harvest and the need to extend harvest seasons to avoid low prices (BASTIANEL et al., 2014; AZEVEDO et al., 2017).

The 'Pera' sweet orange has historically stood out as the most popular and economically important scion variety for juice in Brazil (SALIBE; TEÓFILO SOBRINHO; MÜLLER, 2002; PASSOS; CUNHA SOBRINHO; SOARES FILHO, 2013). However, new cultivars of sweet oranges have been considered promising for juice production (MACHADO; YALY; BATIANEL, 2011; MARTINS, et al., 2014; CARVALHO et al., 2016a; CARVALHO et al., 2016b; MARTINS; TEODORO; CARVALHO, 2016; GOIS et al., 2016, SILVA et al., 2017). For instance, the 'Pineapple' sweet orange can be cultivated in Brazil's northeastern region in order to yield fruits for juice processing. This orange clone, which was brought from California, USA (PASSOS; CUNHA SOBRINHO; SOARES FILHO, 2013), is a moderately vigorous and highly productive plant, whose precocious maturation (SOBRINHO; PASSOS; SOARES, 2004; CAPUTO et al., 2012) occurs in mid-season, i. e., from May to June (MEDEIROS et al., 2013). Its fruits exhibit light orange pulp and rind, besides a large number of seeds (PASSOS; CUNHA SOBRINHO; SOARES FILHO, 2013).

Insertion of alternative citrus varieties in traditional ones has shown that the former have adapted well to several regions, a fact that has led to increase in productivity and fruit quality for both in natura fruit markets and industries (MARTINS et al., 2014; CAPUTO et al., 2012), besides mitigating negative impacts caused by abiotic and biotic stress in citrus groves (MACHADO; YALY; BATIANEL, 2011; FIDALSKI; SCAPIM; STENZEL, 2007; FRANÇA, et al., 2016). The recommendation of the combination scion/rootstock may be evaluated by characteristics such as growth, vigor, precocious production, volume of production, fruit development, fruit maturation, fruit quality, water deficit tolerance and disease/pest tolerance (SILVA et al., 2017). Since, in the same conditions, some rootstocks stand out in certain aspects (MARTINS; TEODORO; CARVALHO, 2016), studies of adaptation and adequate selection are fundamental in order to recommend cultivars (AULER et al., 2008).
Concerning phytossanitary problems, a variety of pests attack citrus orchards in Brazilian northeast including the citrus rust mite Phyllocoptruta oleivora (Acari: Eriophyidae), and the tetranychids Eutetranychus banksi and Tetranychus mexicanus (Acari: Tetranychidae) (MORAES; FLECHTMANN, 2008; MENDONÇA; SILVA, 2009). Therefore, it is also important to assess whether rootstocks would impart plant pest resistance owed to their genetic characteristics.

Therefore, this study aimed to evaluate vegetative, productive, qualitative and phytosanitary performance of 'Pineapple' orange trees grafted on differente rootstocks, so as to recommend combinations that can be grown in the Costal Tablelands of northeastern Brazil.

\section{MATERIAL AND METHODS}

The 'Pineapple' sweet orange grove was stablished in 2008 in the experimental unit at the Embrapa Tabuleiros Costeiros, located in Umbaúba, SE, Brazil $\left(11^{\circ} 22^{\prime} 37^{\prime}\right.$ ' S, $37^{\circ} 40^{\prime} 26^{\prime \prime} \mathrm{W}$ and altitude of $109 \mathrm{~m}$ ). Its soil is dystrophic yellow argisol with weak $\mathrm{Tb}$ A fragipan and mediumtextured whereas the climate in the area is tropical wet with dry summers, in Köppen's classification. In the experimental period, means of annual temperature, air relative humidity and precipitation were $24.6^{\circ} \mathrm{C}, 83 \%$ and $1274 \mathrm{~m}$, respectively. The experiment was carried out as a randomized block design with ten treatments (rootstocks) and four replicates. The experiment consisted of 'Pineapple' grafted on the following rootstocks: 'Santa Cruz Rangpur' lime and 'Red Rough' lemon (C. jambhiri Lush.), 'Orlando' tangelo (C. paradisi Macfad. x $C$. tangerina hort. ex Tanaka 'Sunki Tropical' $[C$. sunki (Hayata) hort. ex Tanaka] mandarin, 'Swingle' citrumelo $[C$. paradisi $\mathrm{x}$ Poncirus trifoliata (L.) Raf.], 'Indio' and 'Riverside' citrandarins (C. sunki $\mathrm{x} P$. trifoliata), and HTR - 051 (hybrid involving $P$. trifoliata), LVK (' $C$. volkameriana $\mathrm{V}$. Ten et Pasq.) x LCR ('Rangpur' lime) - 010 and TSKC (common 'Sunki' mandarin) $\mathrm{x}$ CTTR ['Troyer' citrange $(C$. sinensis $\mathrm{x} P$. trifoliata)] - 002, generated in the Citrus Breeding Program of Embrapa Cassava \& Fruits.

Liming and fertilization in the area under cultivation were based on results of soil analyses, in agreement with Sobral et al. (2007). Experimental plots consisted of two plants, spaced $6.0 \mathrm{~m} \times 4.0 \mathrm{~m}$ apart. Plants, whose density was 416 plants. ha ${ }^{-1}$, were managed in a conventional production system, without irrigation. Cultural practices were the usual recommended by Embrapa for citrus orchards, such 
as fertilizers, conditioners, phytosanitary control and pruning.

Evaluations of plant height $(\mathrm{PH})$, canopy volume $(\mathrm{CV})$, rootstock/scion relation (RSR) and production efficiency (PE) were carried out in 2016. PH was measured by a graduated ruler up the trunk of the tree from the ground to the top. CV was calculated by the formula $\mathrm{V}=(\pi / 6) \times \mathrm{H} \times \mathrm{RD} \times \mathrm{PD}$, where $\mathrm{V}$ is the volume $\left(\mathrm{m}^{3}\right), \mathrm{H}$ is the height (m), RD is the diameter measured parallel to the row and PD is the diameter measured perpendicular to the row (CANTUARIAS-AVILÉS et al., 2011). Trunk diameter was measured by a caliper rule, $10 \mathrm{~cm}$ above (SD) and $10 \mathrm{~cm}$ below the grafted point (GPD). The ratio between both enabled RSR to be estimated. In addition, daily precipitation was recorded by a rain gauge in the experimental area. Drought tolerance (DT) was determined by eye of the level of water deficit plants exhibited in severe drought periods (December to April 2011, 2012, 2013 and 2014). They were classified in terms of their tolerance and susceptibility to lack of soil moisture. Evaluation was carried out in agreement with the following criteria. Grade 1 (susceptible to drought - wilt, yellowing and drop of leaves), grade 2 (moderate drought tolerance - intermediate wilt, yellowing and no leaf drop) to grade 3 (tolerant to drought - no visual symptoms). Survival (SI) was calculated by the percentage of trees kept alive up to 2016.

All fruits harvested in 2011-2017 harvets were counted and weighed. Fruit weight was determined by a precision weighing scale. Estimate of yield $\left(\mathrm{t} \mathrm{ha}^{-1}\right)$ was based on data on production and plant density. Estimations of cumulative yield was based on data on production from 2011 to 2017. Yield efficiency was estimated by the relation between fruits per plant and canopy volume (only in the 2017 harvest). The quality of six fruits per plant was evaluated in 2014-2015 crops, in agreement with Instituto Adolfo Lutz (2008). Juice yield was determined by the calculation [(juice mass/fruit sample mass) x 100], expressed as percentage. Juice mass was calculated by the difference between total fruit mass and bagasse mass (rind, seeds and other fragments retained by the sieve). Total soluble solids (TSS) were expressed as ${ }^{\circ}$ Brix, by an Atago digital handheld refractometer, model Palette PR-32 alpha, whose values were corrected to $20^{\circ} \mathrm{C}$. Total titratable acidity (TTA) was determined by an automatic burette: $0.1 \mathrm{~N} \mathrm{NaOH}$ was the titratable solution while phenolphthalein was the indicator. Results were expressed as g citric acid per $100 \mathrm{~mL}$ juice. The ratio was determined by the arithmetic ratio between TSS and TTA. Vitamin C content, expressed as $\mathrm{mg}$ vitamin $\mathrm{C} / 100 \mathrm{~mL}$ juice, was determined by oxidation-reduction titration, whose standard solution was potassium iodate $\left(\mathrm{KIO}_{3}\right)$ $0.002 \mathrm{~mol} / \mathrm{L}$ and indicator was $1 \%$ starch solution. Technological index (TI) was determined by $\mathrm{TI}=$ juice yield $\mathrm{x}$ total soluble solids $\mathrm{x} 40.8) / 10.000$, equivalent to the amount of TSS in the juice $(\mathrm{kg})$, in a 40.8-kg harvest crate, which corresponds to a standard industrial citrus container. Data were submitted ANOVA and means were compared by the Scott-Knott's test $(\mathrm{P}<0.05)$.

Multivariate analyses were also performed using XLSTAT ${ }^{\circledR}$ add-in for Excel ${ }^{\circledR}$ so as to identify homogenous groups of rootstocks considering the universe of all variables that were significant by univariate ANOVAs. For instance, these variables were: plant height, canopy volume, rootstock:scion girth ratio and survival rate for vegetative development; cumulative yield (2011-2017) for productive performance and fruit mass, fruit diameter, rind thickness, juice content, total soluble solids (TSS), ascorbic acid and TSS/box for fruit quality. First, a Principal Component Analysis (PCA) was applied to evaluate the variability and relationships among the aforementioned variables and the rootstocks. Then, the rootstocks were grouped by Agglomerative Hierarchical Clustering (AHC) using the Euclidean distance as a measure of dissimilarity and the Ward method for linkage. Automatic truncation option was used for cluster splitting. This approach creates homogenous groups based on the largest decrease in Shannons's entropy between a node and the next one.

We further assessed the population densities of three pest mites, namely the rust mite Phyllocptruta oleivora oleivora, and the tetranychids Eutetranychus banksi and Tetranychus mexicanus, on "Pineapple" sweet orange grafted in the 10 rootstocks described previously. The number of adults of the rust mite was recorded in 11 months, spanning from April 2011 to November 2012, in 1$\mathrm{cm}^{2}$ areas of two randomly-selected fruits per plant in each evaluation. The number of adults of $E$. banksi was counted for 13 months, within the period of June 2011 to February 2013, while adults of $T$. mexicanus were recorded for 11 months, within the period of June 2011 to January 2013. Both species were counted in four leaves per plant in each evaluation. Mites were counted in all four plants of the experimental plot. Repeated measures ANOVAs were carried out to compare population densities of $P$. oleivora, E. banksi and T. mexicanus among rootstocks, removing variance explained by time as evaluations were conducted monthly. Data were log 
(x) +1 transformed to achieve assumptions of a normal distribution.

\section{RESULTS AND DISCUSSION}

'Pineapple' sweet orange was found to have different behavior regarding drought tolerance among the rootstocks (Figure 1). The ones grafted on both hybrids LVK $x$ LCR - 010 and TSKC $x$ CTTR - 002 and on the 'Cravo Santa Cruz Rangpur' lime had the highest level of drought tolerance (DT), followed by those grafted on 'Indio' and 'Riverside' citrandarins, 'Red Rough' lemon, 'Sunki Tropical' mandarin and on the hybrid HTR - 051. Carvalho et al. (2016a) found similar results of high level of DT conferred by rootstocks LVK x LCR 010 and 'Cravo Santa Cruz Rangpur' lime to the 'Piemonte' mandarin ['Clementina' mandarin $(C$. clementina hort. ex Tanaka) $\mathrm{x}$ tangor $(C$. sinensis $\mathrm{x}$ C. reticulata Blanco) 'Murcott']. In addition, Carvalho et al. (2016b) observed that rootstocks common 'Rangpur' lime, 'Cravo Santa Cruz
Rangpur' lime, 'Red Rough' lemon, 'Indio' and 'San Diego' citrandarins, as well as the hybrids TSKC x CTSW - 058, TSKFL x CTARG - 028, TSKC $x$ (LCR $\times$ TR) - 059, TSKC x CTARG - 044 and TSKC $x$ LHA - 006, enabled the 'Pera CNPMFD6' sweet orange, to lose little water by evapotranspiration and show high production efficiency in conditions of natural water deficit. In dry farming in Colômbia, SP, Brazil, Ramos et al. (2015) found that 'Valência' sweet orange grafted on 'Indio' and 'Riverside' citrandarins had high production and vigor, even though their leaves showed symptoms of wrinkling as the result of drought in the region. Water deficit leads to decrease in photosynthesis rates by means of both stomatal and non-stomatal limitations. However, the most adapted plants respond with osmotic adjustment enabled by the accumulation of solutes, such as proline. It makes plants keep leaf turgor, which is needed for stomatal opening in low water conditions, besides favoring water absorption by roots (BLUM, 2009; CARVALHO et al., 2016b).

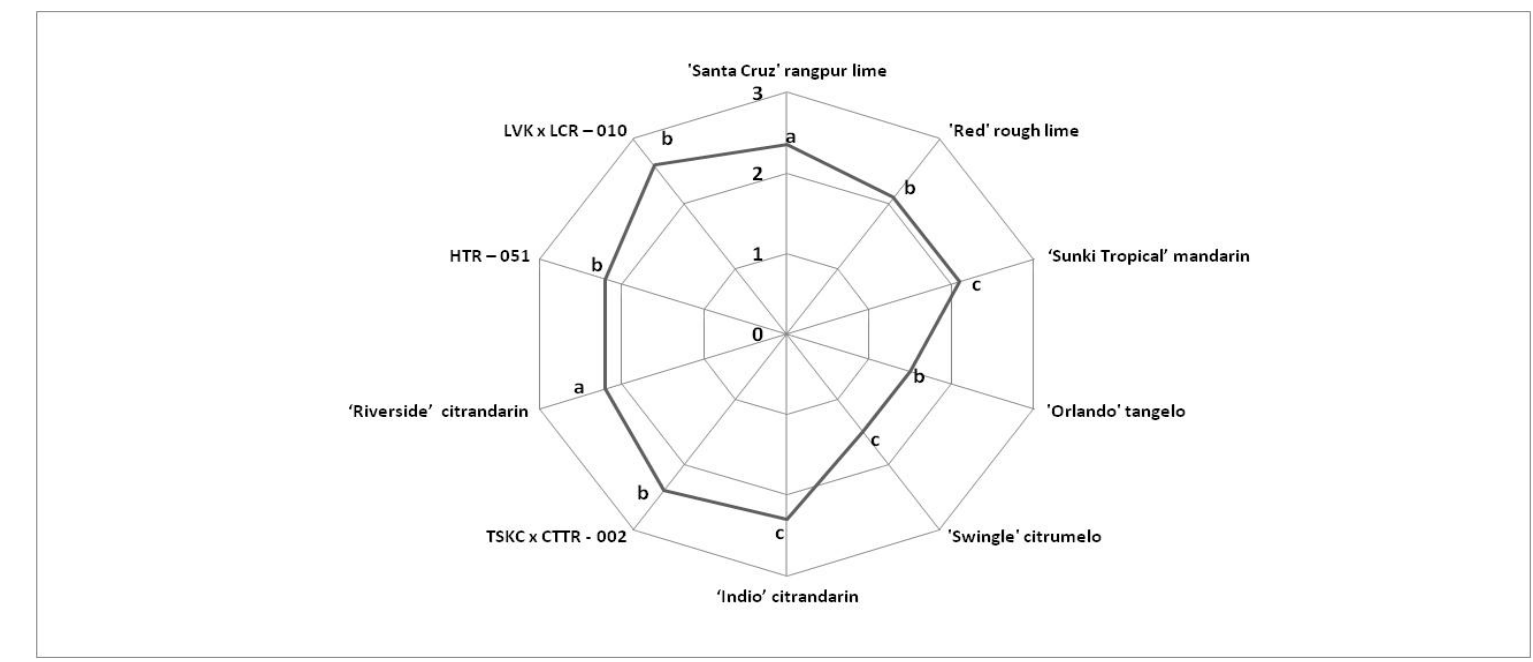

Figure 1. Drought tolerance (DT) of the 'Pineapple' sweet orange [Citrus sinensis (L.) Osbeck] grafted on different rootstocks, in conditions found in Coastal Tablelands, of northeastern Brazil, from December to April 2011-2014.

Means followed by the same letter do not differ from each other according to Scott-Knott's test at 5\% probability. DT values ranged from 1 (susceptible to drought) to 3 (tolerant to drought). *'Red Rough' lemon (C. jambhiri Lush.), 'Santa Cruz' Rangpur lime (C. limonia Osbeck), VKL ('Volkamer' lemon C. volkameriana V. Ten. et Pasq.) x LCR ('Rangpur' lime) - 010 hybrid, 'Sunki' Tropical mandarin [C. sunki (Hayata) hort. ex Tanaka], 'Indio' and 'Riverside' citrandarins (C. sunki x P. trifoliata), 'Orlando' tangelo (C. paradisi Macfad. x C. tangerina hort. ex Tanaka), 'Swingle' citrumelo [C. paradisi x Poncirus trifoliata (L.) Raf.], TSKC (common 'Sunki' mandarin) x CTTR ['Troyer' citrange (C. sinensis x P. trifoliata)] - 002 and HTR [trifoliate hybrid involving Poncirus trifoliata (L.) Raf.] - 051.

Rootstocks 'Orlando' tangelo and 'Swingle' citrumelo showed low tolerance to drought and symptoms, ranging from leaf wilting and yellowing of low leaves to wrinkling and slight fall of old leaves. Symptoms of water deficit in citrus plants have been often observed in the region Coastal Tablelands, in Bahia and Sergipe states (SOUZA;
SOUZA; LEDO, 2007), even when the rootstock is the 'Cravo' lime, which is known to induce high drought tolerance to scion varieties (POMPEU JÚNIOR; BLUMER, 2011; CUNHA SOBRINHO et al., 2013). Cerqueira et al. (2004) reported that HTR - 051 has good results when it undergoes a period of water deficit followed by hydration, 
whereas the 'Orlando' tangelo, the 'Swingle' citrumelo and the 'San Diego' citrandarin show lower water deficit tolerance in this period. It corroborates results on the 'Swingle' citrumelo and the 'Orlando' tangelo, which are less tolerant to drought (PRUDENTE; SILVA; CUNHA SOBRINHO, 2004; CUNHA SOBRINHO et al., 2013; CARVALHO et al., 2016a).

Regarding the relation between trunk diameters below/above grafts, the 'Swingle' citrumelo and the 'Riverside' citrandarin exhibited a value which was higher than 1 ; consequently, there was greater difference among the diameters and both differed from the other rootstocks (Table 1). The difference among trunk diameters in scion and rootstock combinations may be an indicator of compatibility (STENZEL et al., 2005), but it depends on confirmation after examining of gum on the graft point, which is considered an evidence of incompatibility, with short-lived trees that yield few fruits (POMPEU JUNIOR; BLUMER, 2014). Even though results were close to 1 , problems related to incompatibility were not visually observed, except in the 'Swingle' citrumelo (1.72), whose value infers the tendency to incompatibility between scion and rootstock. Although it is known that the 'Swingle' citrumelo is incompatible with the 'Pêra' orange (POMPEU JUNIOR \& BLUMER, 2014), the 'Valência' sweet orange (POMPEU JUNIOR; BLUMER, 2009) and mandarin (BARBASSO et al., 2005), there is no specific information on the 'Pineapple' sweet orange.

Table 1. Rootstock:scion girth ratio, plant height, canopy volume, yield efficiency (YE), survival of the 'Pineapple' sweet orange [Citrus sinensis (L.) Osbeck] grafted on different rootstocks. Municipality of Umbaúba, SE, Brazil. 2016.

\begin{tabular}{llllll}
\hline Rootstocks * & $\begin{array}{l}\text { Rootstock:scion } \\
\text { girth ratio }\end{array}$ & $\begin{array}{l}\text { Plant height } \\
(\mathrm{m})\end{array}$ & $\begin{array}{l}\text { Canopy } \\
\text { volume }\left(\mathrm{m}^{3}\right)\end{array}$ & $\begin{array}{l}\text { YE }\left(\mathrm{kg} \cdot \mathrm{m}^{-}\right. \\
\text {3 }\end{array}$ & $\begin{array}{l}\text { Survival } \\
\%\end{array}$ \\
\hline 'Red Rough' lemon & $1,16 \mathrm{a}$ & $3,02 \mathrm{a}$ & $17,60 \mathrm{a}$ & $6,30 \mathrm{a}$ & 75 \\
'Santa Cruz Rangpur' lime & $1,24 \mathrm{a}$ & $2,83 \mathrm{a}$ & $12,60 \mathrm{~b}$ & $6,8 \mathrm{a}$ & 100 \\
LVK x LCR - 010 & $1,15 \mathrm{a}$ & $2,92 \mathrm{a}$ & $14,80 \mathrm{a}$ & $6,80 \mathrm{a}$ & 100 \\
'Sunki Tropical' mandarin & $1,27 \mathrm{a}$ & $2,70 \mathrm{a}$ & $13,40 \mathrm{~b}$ & $6,80 \mathrm{a}$ & 87 \\
'Indio' citrandarin & $1,37 \mathrm{a}$ & $2,68 \mathrm{a}$ & $12,30 \mathrm{~b}$ & $6,00 \mathrm{a}$ & 100 \\
'Orlando' tangelo & $1,27 \mathrm{a}$ & $2,94 \mathrm{a}$ & $15,80 \mathrm{a}$ & $7,00 \mathrm{a}$ & 100 \\
'Riverside' citrandarin & $1,45 \mathrm{~b}$ & $2,32 \mathrm{~b}$ & $8,60 \mathrm{~d}$ & $7,30 \mathrm{a}$ & 87 \\
'Swingle' citrumelo & $1,72 \mathrm{~b}$ & $2,44 \mathrm{~b}$ & $8,20 \mathrm{~d}$ & $7,00 \mathrm{a}$ & 62 \\
TSKC x CTTR - 002 & $1,08 \mathrm{a}$ & $2,51 \mathrm{~b}$ & $6,80 \mathrm{e}$ & $6,00 \mathrm{a}$ & 75 \\
HTR - 051 & $1,29 \mathrm{a}$ & $2,17 \mathrm{~b}$ & $5,20 \mathrm{e}$ & $8,50 \mathrm{a}$ & 100 \\
\hline Means & 1,32 & 2,65 & 11,50 & 6,09 & \\
CV $(\%)$ & 12,38 & 10,47 & 13,87 & 14,89 & \\
\hline
\end{tabular}

Means followed by the same letter within columns belong to the same grouping according to Scot-Knott (5\%) tests.

*'Red Rough' lemon (C. jambhiri Lush.), 'Santa Cruz' Rangpur lime (C. limonia Osbeck), VKL ('Volkamer’ lemon C. volkameriana V. Ten. et Pasq.) x LCR ('Rangpur' lime) - 010 hybrid, 'Sunki' Tropical mandarin [C. sunki (Hayata) hort. ex Tanaka], 'Indio' and 'Riverside' citrandarins (C. sunki x P. trifoliata), 'Orlando' tangelo (C. paradisi Macfad. x C. tangerina hort. ex Tanaka), 'Swingle' citrumelo [C. paradisi x Poncirus trifoliata (L.) Raf.], TSKC (common 'Sunki' mandarin) x CTTR ['Troyer' citrange (C. sinensis x P. trifoliata)] - 002 and HTR [trifoliate hybrid involving Poncirus trifoliata (L.) Raf.] - 051.

Rootstocks induced differences in the height and canopy volume of 'Pineapple' sweet orange. Two groups of plants were observed regarding their scion heights. In the group with the highest trees, heights ranged from 2.68 to $3.02 \mathrm{~m}$, whereas in the group with the shortest trees, values of rootstocks HTR-051, 'Riverside' citrandarin, 'Swingle' citrumelo and TSKC x CTTR-02 ranged from 2.17 to $2.51 \mathrm{~m}$ (Table 1). Rootstocks that led to the lowest heights also led to the smallest canopy volumes. Likewise, rootstocks 'Rugoso Vermelho' lemon, 'Orlando' tangelo and LVK x LCR-010 enabled the highest scion development eight years after the trees were planted. Rootstocks 'Sunki Tropical' mandarin, 'Indio' citrandarin and 'Cravo Santa Cruz' lime followed (Table 1).

There is a tendency to plant densification in citrus fruit groves due to the need to mitigate problems related to manpower shortage, to carry out cultural practices and facilitate harvest and to enable mechanization. The search for scion and rootstock varieties which are adequate to denser citrus spacing has been the subject of several Brazilian experiments. According to Carvalho et al. (2016a), tree size is important to plan new groves, since small trees enable increase in plant density in a certain area. Stuchi et al. (2008) reported small citrus trees grafted on 'Swingle' citrumelo, a fact 
that suggests that they may be adopted in denser cultures. Likewise, Carvalho et al. (2016a) observed that rootstocks HTR-051 and 'Swingle' citrumelo led to small scions in 'Piemonte' mandarin. On the other hand, the 'Orlando' tangelo induced the development of higher plants. Citrandarins are hybrids of mandarins and trifoliata orange $(P$. trifoliata) that aim at developing tolerance to diseases and inducing reduction in plant size (POMPEU JUNIOR; BLUMER, 2011).

In contrast with the search for rootstocks that induce small scions, vigorous plants are more capable of yielding more fruits. However, shading inside the scion may lead to decrease in production efficiency, since the productive area of the scion is located in the external layer which is 1-meter deep and captures $90 \%$ solar radiation (NÚNEZ; MOURÃO FILHO; STUCHI, 2007). Less vigorous plants endure cultural densification easily, profit more from fertilizers, more efficiency from phytosanitary treatments and have their harvest simplified and, consequently, cheaper; thus, they become an efficient productive unit (POMPEU JUNIOR; BLUMER 2009; AZEVEDO et al., 2015).

Yield efficiency of 'Pineapple' orange grafted on different rootstocks was significantly similar, i. e., eight years after they were planted, they yielded from 6.0 to 8.5 fruits. $\mathrm{m}^{-3}$. High yield efficiency implies in low production costs and high number of fruits (BLUMER; POMPEU JÚNIOR, 2005). 'Pineapple' orange grafted on rootstocks 'Riverside' citrandarin, TSKC x CTTR - 002, HTR 051 and 'Swingle' citrumelo resulted in small trees and showed that these materials have potential to be used in dense cultures. Bastos et al. (2014) stated that, in citrus rootstock diversification, the aim is to get dwarfing rootstocks. It enables high yield efficiency due to increase in culture density and, consequently, high production per area unit. It should be highlighted that rootstocks HTR-51, LVK $\mathrm{x}$ LCR-010 and 'Cravo Santa Cruz' lime had the highest survival rates $(100 \%)$, whereas 'Riverside' citrandarin, TSKC X CTTR-02 (75\%) and 'Swingle' citrumelo (62\%) resulted in plant death of $13 \%, 25 \%$ and $38 \%$, respectively (Table 2). França et al. (2016) observed that the 'Valencia Tuxpan' orange grafted on 14 rootstocks exhibited an high survival rates $(100 \%)$, after having grown for nine years. The best rootstocks were both 'Indio' and 'Riverside' citrandarin, 'Sunki Tropical' mandarin and 'Cravo Santa Cruz Rangpur' lime, whereas the hybrid TSKFL x CTSW - 049 was the only rootstock that led to plant death.
Regarding their performance in production, 'Pineapple' orange grafted on 'Rugoso Vermelho' and 'Cravo Santa Cruz Rangpur' lime stood out in six harvests in the first seven production years (from 2011 to 2017) (Table 2). However, in four harvests, the trees grafted on the hybrid TSKFL $x$ CTSW 049 were the most productive and, in three harvests, rootstocks 'Sunki Tropical' mandarin and both 'Indio' and 'Riverside' citrandarins yielded the most. On the other hand, rootstocks with the lowest performance in production were HTR - 051 (seven harvests), TSKC x CTTR - 02, 'Swingle' citrumelo and 'Orlando' tangelo (six harvests). In this period, cumulative yield of rootstocks 'Red Rough' lemon and 'Cravo Santa Cruz Rangpur' lime, hybrid LVK $\mathrm{x}$ LCR - 010 and 'Sunki Tropical' mandarin was over 120 thousand kg.ha-1 (Table 2). Even though rootstocks 'Indio' citrandarin (112 t.ha $\left.{ }^{-1}\right)$, 'Orlando' tangelo (108 t.ha ${ }^{-1}$ ) and 'Riverside' citrandarin (102 t.ha ${ }^{-1}$ ) had lower production than the previous ones, their cumulative yield was higher comparison with the other cultivars. The lowest cumulative yield found in this period was the one of rootstocks 'Swingle' citrumelo, TSKC x CTTR - 002 and HTR - 051. Likewise, Carvalho et al. (2016a) carried out a 4-year study and found low cumulative yield of 'Piemonte' mandarin when they were grafted on rootstocks 'Orlando' tangelo, 'Swingle' citrumelo and HTR - 051. On the other hand, 'Cravo Santa Cruz Rangpur' lime and 'Sunki Tropical' mandarin induced high cumulative production to 'Valencia Tuxpan' orange in a 5-year study (FRANÇA et al., 2016), whereas the 'Cravo Santa Cruz' lime also impart high production to the 'Piemonte' mandarin (CARVALHO et al., 2016a).

Except the ratio, titratable acidity and fruit height, physical and chemical criteria of fruits were significantly affected by the rootstock (Table 3 ). Besides, there were differences in criteria, except for fruit diameter. Rootstocks had the same behavior in the average of all years, except bark thickness, whose responses differed (Table 3). Fruits from 'Pineapple' orange grafted on 'Red Rough' lemon and 'Cravo Santa Cruz Rangpur' lime, LVK x LCR - 010, 'Orlando' tangelo and HTR - 051 had the highest fruit mass and diameter (Table 3). Rind thickness depended on the rootstock, for instance, fruits from trees grafted on the 'Red Rough' lemon had the thickest rind, whereas those from plants grafted on the 'Orlando' tangelo and HTR - 051 had the thinnest rind, despite being heavier and larger than the others, followed by fruits from trees grafted on 'Indio' citrandarin and 'Swingle' citrumelo. 
Table 2. Annual and cumulative yields of ten citrus rootstocks in combination with the 'Pineapple' sweet orange [Citrus sinensis (L.) Osbeck] grown in Costal Tablelands, in northeastern Brazil, in harvests from 2011 to 2017.

Means followed by the same letter in the column belong to the same group according to the method Scott-Knott $(\mathrm{P} \leq 5 \%)$.

\begin{tabular}{|c|c|c|c|c|c|c|c|c|}
\hline \multirow{2}{*}{ Rootstocks* } & \multicolumn{7}{|c|}{ Yield $\left(\mathrm{kg} \cdot \mathrm{ha}^{-1}\right)$} & \multirow{2}{*}{$\begin{array}{l}\text { Cumulative } \\
\text { yield (kg.ha- } \\
\text { 1) }\end{array}$} \\
\hline & 2011 & 2012 & 2013 & 2014 & 2015 & 2016 & 2017 & \\
\hline 'Red Rough' lemon & $9013 a$ & $10932 \mathrm{a}$ & $12078 \mathrm{a}$ & $19536 a$ & $47895 a$ & $30238 a$ & $13484 b$ & $139589 a$ \\
\hline 'Santa Cruz Rangpur' lime & $8262 a$ & $11435 a$ & $13133 a$ & $16200 \mathrm{a}$ & $34305 b$ & $24649 a$ & $20342 a$ & $126804 a$ \\
\hline LVK x LCR - 010 & $6143 b$ & $13375 a$ & $12698 \mathrm{a}$ & $14951 a$ & $36519 b$ & $30212 a$ & $12541 b$ & $126440 \mathrm{a}$ \\
\hline 'Sunki Tropical' mandarin & $9225 a$ & $8832 b$ & $9358 b$ & $14531 \mathrm{a}$ & $38640 \mathrm{~b}$ & $28673 a$ & $10975 b$ & $120169 a$ \\
\hline 'Indio' citrandarin & $9540 \mathrm{a}$ & $10791 b$ & $10083 b$ & $16463 a$ & 29561c & $23416 a$ & $12173 b$ & $112026 b$ \\
\hline 'Orlando' tangelo & $6709 b$ & $8971 b$ & $8838 b$ & $11454 b$ & $36223 b$ & $24267 a$ & $14651 b$ & $108040 b$ \\
\hline 'Riverside' citrandarin & $8636 a$ & $9193 c$ & $10538 \mathrm{~b}$ & $14211 a$ & $25736 c$ & $24377 \mathrm{a}$ & $5498 c$ & $102608 b$ \\
\hline 'Swingle' citrumelo & $3438 \mathrm{c}$ & $8757 c$ & $7100 \mathrm{c}$ & $10257 \mathrm{~b}$ & $26548 c$ & $21621 a$ & $7832 c$ & $86440 \mathrm{c}$ \\
\hline TSKC x CTTR - 002 & $7222 b$ & $10732 b$ & $10235 b$ & $12098 b$ & $23382 c$ & $14838 b$ & - & $77827 \mathrm{c}$ \\
\hline HTR - 051 & $6608 b$ & $6057 \mathrm{c}$ & $9648 b$ & $10617 \mathrm{~b}$ & $17945 \mathrm{c}$ & $11748 b$ & $6583 c$ & $69205 c$ \\
\hline Means & 7685 & 9938 & 10590 & 14140 & 31953 & 23500 & 11175 & 97928 \\
\hline $\mathrm{CV} \%$ & 16,53 & 12,62 & 10,96 & 17,27 & 9,49 & 23,58 & 23,98 & 11,57 \\
\hline
\end{tabular}

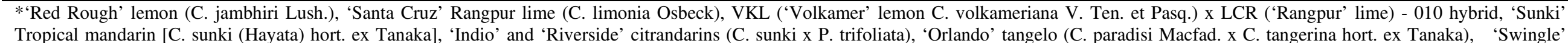

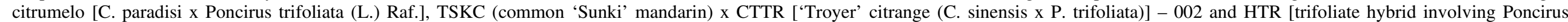
trifoliata (L.) Raf.] - 051. 
Table 3. Means of fruit mass, diameter, height, thickness, juice content, titratable acidity, total soluble solids, vitamin C and technological index (IT)of 'Pineapple' sweet orange [Citrus sinensis (L.) Osbeck] grafted on ten rootstocks grown in Coastal Tablelands of northeastern Brazil during 2014,2015 and 2016 harvests.

\begin{tabular}{|c|c|c|c|c|c|c|c|c|c|c|}
\hline Rootstocks+ & $\begin{array}{l}\text { Fruti mass } \\
(\mathrm{g})\end{array}$ & $\begin{array}{l}\text { Diameter } \\
(\mathrm{mm})\end{array}$ & $\begin{array}{l}\text { Hieght } \\
(\mathrm{mm})\end{array}$ & $\begin{array}{l}\text { Tchickness } \\
(\mathrm{mm})\end{array}$ & $\begin{array}{l}\text { Juice } \\
\text { content } \\
(\%)\end{array}$ & $\begin{array}{l}\text { Titatrable } \\
\text { acidity } \\
\left(\mathrm{g} .100 \mathrm{~mL}^{-1}\right)\end{array}$ & $\begin{array}{l}\text { TSS } \\
\left({ }^{\circ} \text { Brix }\right)\end{array}$ & $\begin{array}{l}\text { Ascorbic } \\
\text { acid-Vit.C } \\
\left(\mathrm{mg} \cdot \mathrm{L}^{-1}\right)\end{array}$ & IT & Ratio \\
\hline 'Red Rough' lemon & $236,00 \mathrm{a}$ & $82,84 a$ & $63,11 \mathrm{a}$ & $4,00 \mathrm{a}$ & $53,02 \mathrm{~b}$ & $0,84 \mathrm{a}$ & $10,76 b$ & $62,43 b$ & $2,33 b$ & $14,99 a$ \\
\hline 'Santa Cruz Rangpur' lime & $218,50 \mathrm{a}$ & $82,81 \mathrm{a}$ & $64,50 a$ & $3,56 b$ & $53,91 b$ & $0,85 \mathrm{a}$ & $11,43 a$ & $66,17 \mathrm{a}$ & $2,48 b$ & $14,58 \mathrm{a}$ \\
\hline LVK x LCR - 010 & $231,25 \mathrm{a}$ & $79,97 \mathrm{a}$ & $62,46 a$ & $3,60 \mathrm{~b}$ & $54,04 \mathrm{~b}$ & $0,85 \mathrm{a}$ & $12,20 \mathrm{a}$ & $68,35 a$ & $2,70 \mathrm{a}$ & $15,38 \mathrm{a}$ \\
\hline 'Sunki Tropical' mandarin & $213,75 b$ & $77,04 b$ & $61,95 a$ & $2,87 \mathrm{~d}$ & $57,47 \mathrm{a}$ & $0,92 \mathrm{a}$ & $11,55 \mathrm{a}$ & $67,37 \mathrm{a}$ & $2,71 \mathrm{a}$ & $13,86 \mathrm{a}$ \\
\hline 'Indio' citrandarin & $216,25 b$ & $78,85 b$ & $62,87 \mathrm{a}$ & $3,16 \mathrm{c}$ & $56,44 a$ & $0,87 \mathrm{a}$ & $11,78 \mathrm{a}$ & $64,40 b$ & $2,72 \mathrm{a}$ & $13,87 \mathrm{a}$ \\
\hline 'Orlando' tangelo & $222,50 \mathrm{a}$ & $80,06 a$ & $63,08 \mathrm{a}$ & $3,30 \mathrm{c}$ & $57,16 a$ & $0,87 \mathrm{a}$ & $10,75 b$ & $61,72 b$ & $2,52 \mathrm{~b}$ & $14,63 \mathrm{a}$ \\
\hline 'Riverside' citrandarin & $207,00 \mathrm{~b}$ & $76,26 b$ & $61,37 \mathrm{a}$ & $2,89 d$ & $56,43 a$ & $0,89 \mathrm{a}$ & $11,94 \mathrm{a}$ & $65,31 \mathrm{a}$ & $2,74 a$ & $14,02 \mathrm{a}$ \\
\hline 'Swingle' citrumelo & $200,00 \mathrm{~b}$ & $75,92 b$ & $62,85 a$ & $3,29 \mathrm{c}$ & $57,32 \mathrm{a}$ & $0,91 \mathrm{a}$ & $11,75 \mathrm{a}$ & $62,57 \mathrm{~b}$ & $2,74 a$ & $14,22 \mathrm{a}$ \\
\hline TSKC x CTTR - 002 & $209,00 \mathrm{~b}$ & $78,16 b$ & $70,50 \mathrm{a}$ & $2,86 \mathrm{~d}$ & $55,52 \mathrm{a}$ & $0,84 \mathrm{a}$ & $11,83 \mathrm{a}$ & $66,77 \mathrm{a}$ & $2,67 \mathrm{a}$ & $14,69 \mathrm{a}$ \\
\hline HTR - 051 & $224,25 \mathrm{a}$ & $79,96 a$ & $64,17 \mathrm{a}$ & $3,31 \mathrm{c}$ & $56,83 a$ & $0,85 \mathrm{a}$ & $11,88 \mathrm{a}$ & $66,47 \mathrm{a}$ & $2,75 \mathrm{a}$ & $14,52 \mathrm{a}$ \\
\hline Means & 218,02 & 78,85 & 63,51 & 3,27 & 55,87 & 0,87 & 11,63 & 65,28 & 2,65 & 14,45 \\
\hline $\mathrm{CV}(\%)$ & 5,35 & 4,33 & 12,45 & 10,34 & 4,53 & 9,33 & 7,00 & 6,08 & 8,67 & 10,21 \\
\hline $\mathrm{F}$ (Treatment) & - & $4,10 *$ & $0,80 \mathrm{~ns}$ & $8,53 * *$ & $2,95 * *$ & $1,02 \mathrm{~ns}$ & $2,80 * *$ & $2,48^{*}$ & $3,13 * *$ & $0,82 \mathrm{~ns}$ \\
\hline $\mathrm{F}($ Year $)$ & - & $0,11 \mathrm{~ns}$ & $91,47 * *$ & $250,35 * *$ & $59,13 * *$ & $224,14 * *$ & $7,80 * *$ & $25,79 * *$ & $44,16 * *$ & $126,60 * *$ \\
\hline F (Treatment $x$ Year) & - & $1,92 \mathrm{~ns}$ & $1,79 \mathrm{~ns}$ & $3,72 * *$ & $1,18 \mathrm{~ns}$ & $1,02 \mathrm{~ns}$ & $1,31 \mathrm{~ns}$ & $1,55 \mathrm{~ns}$ & $1,11 \mathrm{~ns}$ & $1,63 \mathrm{~ns}$ \\
\hline
\end{tabular}

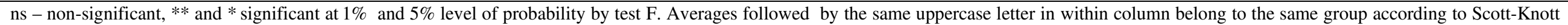
test.

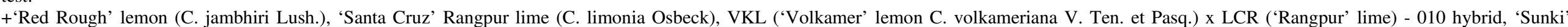

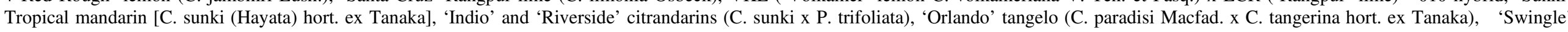

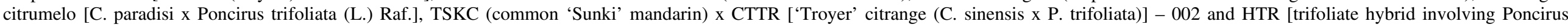
trifoliata (L.) Raf.] - 051. 
Concerning juice yield, fruits from trees grafted on rootstocks that had the highest mass and the thickest rind showed the least juice yield (53.02\% and 54.04\%), except rootstocks 'Orlando' tangelo and HTR - 051, which had the highest juice yield, yielding $57.16 \%$ and $56.83 \%$, respectively. According to Duarte et al. (2011), rind thickness reflects mainly on juice yield, i.e., the thinner the rind, the better the yield. The 'Pineapple' orange grafted on LVK-CLEO-264, grown in Brejão, Pernambuco, exhibited juice yield of $54 \%$ (MEDEIROS et al., 2013). It is below the highest values here, since they are high and above minimum requirements the Programa Brasileiro para Modernização da Horticultura (2011), which is $45 \%$. Negreiros et al. (2014) stated that, in hot and humid tropical climate, fruits tend to be juicier, depending on the interaction between scion and rootstock.

Fruits from trees grafted on 'Red Rough' lemon and 'Orlando' tangelo had the same content of total soluble solids $\left(10.7^{\circ}\right.$ Brix $)$, significantly lower than the one found in the other rootstocks, whose values ranged from 11.55 to $12.20^{\circ}$ Brix. Even though the values, regardless of the rootstock, are above the minimum required by the market, fruits with high TSS content are considered with the best quality (CANTUARIAS-AVILÉS et al., 2011). Medeiros et al. (2013) found values below $10^{\circ}$ Brix in fruits from 'Pineapple' sweet orange tree grown in Pernambuco. In São Paulo (SP), the 'Pineapple' sweet orange grafted on 'Sunki Tropical' mandarin exhibited $11^{\circ}$ Brix (CAPUTO et al., 2012).

Vitamin C content of fruits from the 'Pineapple' sweet orange was influenced by the rootstocks, i. e., it was higher in fruits from trees grafted on 'Cravo Santa Cruz Rangpur' lime, LVK x LCR - 010, 'Orlando' tangelo, 'Sunki Tropical' mandarin, 'Riverside' citrandarin, TSKC x CTTR 002 and HTR - 051.

Regarding the technological index (TI), variation between 2.33 and $2.78 \mathrm{~kg} . S S . c r a t e^{-1}$ was found. Two fruit groups could be separated: the ones with the lowest TI were obtained from trees grafted on 'Red Rough' lemon (2.33) and 'Cravo Santa Cruz Rangpur' (2.48) lime, as well as on 'Orlando' tangelo (2.52) and the other rootstocks, whose TI's were close to 2.7. High TI values mean fewer fruit crates to produce a ton of juice (CAPUTO et al, 2012). Stuchi, Donadio and Sempionato (2002) studied the effect of seven rootstocks on the quality of fruits yielded by the 'Valência' sweet orange in Bebedouro, SP, and did not find any difference among the rootstocks in terms of acidity, soluble solids, ratio and technological index, which ranged from 2.49 to 2.86 kg.SS. box ${ }^{-1}$. França et al. (2016) found an interval from 1.8 to $2.5 \mathrm{~kg} . \mathrm{SS}$ box $^{-1}$ in the case of 'Valência Tuxpan' sweet orange grafted on 14 rootstocks in the north of Bahia, whereas Bacar et al. (2014) found values that ranged from 1.83 to 1.96 kg.SS.crate ${ }^{-1}$ in 'Jafa' orange trees grafted on 5 rootstocks in Londrina, Paraná state.

About $73 \%$ of the total variability could be explained by the two first axes of the PCA (Figure 2a), and the square cosine of the variables showed that plant height, canopy volume, cumulative yield, fruit mass, fruit diameter, rind thickness, juice content, total soluble solids (TSS) and TSS/box were mostly associated with PC1, whereas rootstock:scion girth ratio (R/S girth ratio), survival rate and ascorbic acid content were associated with PC2. Significant correlations were observed between cumulative yields, canopy volumes and plant heights, indicating that the better the vegetative development, the higher the yield.

In general, small fruits (low mass and diameter) were associated with high $\mathrm{R} / \mathrm{S}$ girth ratio. This variable is an indicator of the grafting compatibility and the closer to 1 , the better the compatibility. Therefore, despite having little effect on vegetative development and yield of 'Pineapple' trees, the worst the grafting compatibility (i.e. the higher the R/S girth ratio), the lower the size of the fruits (mass and diameter) but the higher the juice content.

In relation to attributes of fruit quality, bigger fruits showed thicker peels and lower juice contents and, as consequence, also lower TSS/box. Hence, rootstocks that induced higher juice contents in 'Pineapple' also showed fruits of smaller mass and diameter but produced the largest amounts of TSS/box. Also, ascorbic acid contents were positively and closely associated with total soluble solids.

The AHC grouped the rootstocks into three clusters (Figure 2b). The first one comprised 'Orlando' tangelo and 'Red Rough' lemon and was characterized by better grafting compatibility with 'Pineapple' (mean R/S girth ratio of 1.16), taller plants with large canopy volumes, higher cumulative yields, bigger fruits with lower total soluble solids and ascorbic acid contents. The second cluster included 'Santa Cruz Rangpur' lime and the hybrid LVK $x$ LCR - 010 and was characterized by plants that showed high survival rates and values for vegetative development as well as cumulative yield and fruit mass lower than the first, but bigger than the third cluster (described next). Also, the chemical attributes of the fruits, like 
total soluble solids and ascorbic acid contents were high for these rootstocks. Finally, the third cluster, which enclosed all other rootstocks ('Sunki Tropical' mandarin, 'Indio' and 'Riverside' citrandarins, 'Swingle' citrumelo and the hybrids TSKC x CTTR - 002 and HTR - 051) showed less grafting compatibility with 'Pineapple' (mean R/S

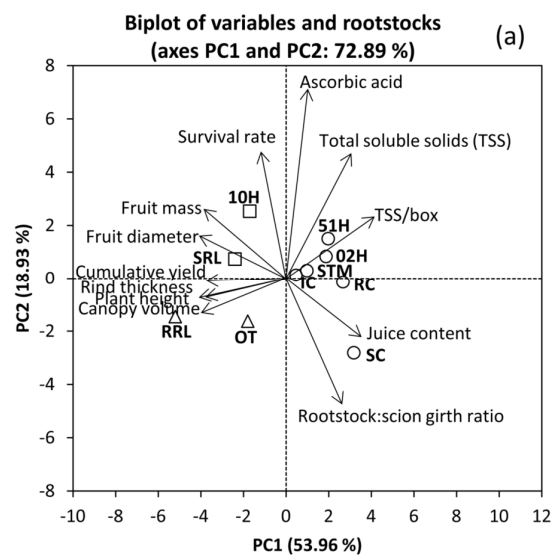

girth ratio as high as 1.45) than the other two clusters. As consequence, on average, these rootstocks induced shorter plants with smaller canopy volumes, lower cumulative yields, smaller fruits (both mass and diameter) with thinner rinds but with higher juice contents, total soluble solids, ascorbic acid and SST/box.

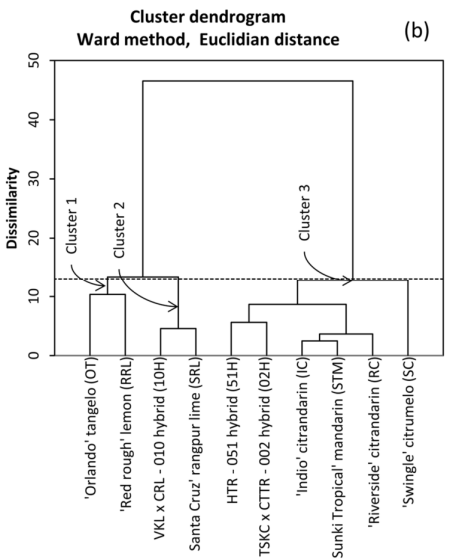

Figure 2. Biplot of variables and rootstocks of the Principal Component Analysis (a) and dendrogram (b) obtained by Agglomerative Hierarchical Clustering for ten rootstocks for 'Pinapple' sweet orange (Citrus sinensis Osb.]) in Umbauba, state of Sergipe, Brazil.

Notes: Cluster $1(\Delta)$ - 'Orlando' tangelo (OT) and 'Red Rough' lemon (RRL); Cluster $2(\square)-$ VKL x CRL - $010(\mathbf{1 0 H})$ and 'Santa Cruz' Rangpur lime (SRL); Cluster 3 ( () - HTR - 051 hybrid (51H), TSKC x CTTR - 002 hybrid (02H), 'Indio' citrandarin (IC), 'Riverside' citrandarin (RC) and 'Swingle' citrumelo (SC)

Regarding phytossanitary constraints, plant resistance to pests is one of several strategies of integrated management programs (GALLO et al., 2002; CHACÓN; ASPLEN; HEIMPEL, 2012), helping to keep pest populations in check (VENDRAMIM; GUZZO, 2011). However, we did not find evidence of plant resistance as population densities of P. oleivora, E. banksi and T. mexicanus on 'Pineapple' orange were not influenced by rootstocks (Figure 3; $\mathrm{F}_{9,28}=0.468 ; \mathrm{P}=0.888$ for $P$. oleivora; $\mathrm{F}_{9,29}=1.02 ; \mathrm{P}=0.446$ for E. banksi and $\mathrm{F}_{9,29}=0.529 ; \mathrm{P}=0.841$ for $T$. mexicanus). Such results are in line with previous evaluations conducted in the same region in which natural infestations of the pest mites P. oleivora, E. banksi and T. mexicanus on 'Piemonte' mandarin were not influenced by rootstocks (CARVALHO et al. 2016).

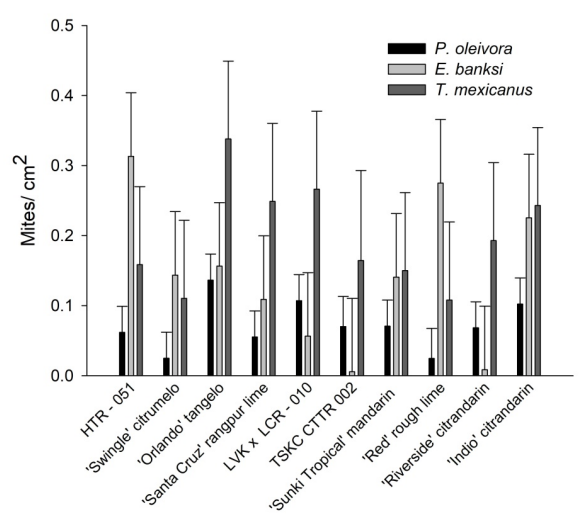

Figure 3. Population densities of the pest mites P. oleivora, E. banksi and T. mexicanus on 'Pineapple' sweet orange grafted in ten rootstocks. Means $+\mathrm{SE}$ of $\log (\mathrm{x}+1)$ transformed data are shown.

*'Red Rough' lemon (C. jambhiri Lush.), 'Santa Cruz' Rangpur lime (C. limonia Osbeck), VKL ('Volkamer' lemon C. volkameriana V. Ten. et Pasq.) x LCR ('Rangpur' lime) - 010 hybrid, 'Sunki' Tropical mandarin [C. sunki (Hayata) hort. ex Tanaka], 'Indio' and 'Riverside' citrandarins (C. sunki x P. trifoliata), 'Orlando' tangelo (C. paradisi Macfad. x C. tangerina hort. ex Tanaka), 'Swingle' citrumelo [C. paradisi x Poncirus trifoliata (L.) Raf.], TSKC (common 'Sunki' mandarin) $x$ CTTR ['Troyer' citrange (C. sinensis x P. trifoliata)] - 002 and HTR [trifoliate hybrid involving Poncirus trifoliata (L.) Raf.] 051. 


\section{CONCLUSIONS}

Rootstocks induced differences in the height and canopy volume of 'Pineapple' sweet orange.

Both hybrids LVK x LCR - 010 and TSKC $x$ CTTR - 002 and 'Cravo Santa Cruz Rangpur' lime bestow high drought tolerance whereas 'Orlando' tangelo and 'Swingle' citrumelo conferred drought susceptibility to 'Pineapple' plants.

Rootstock/scion compatibility does not affect plant height and canopy volume but has a negative effect on fruit size and a positive influence on juice content of 'Pineapple' sweet orange.

Rootstocks HTR - 051, 'Riverside' citrandarin, 'Swingle' citrumelo and TSKC x CTTR - 002 induced small plants and, thus, capable of leading to high density plantings.

Cumulative yield of 'Pineapple' orange is higher when grafted on the following rootstocks: 'Red Rough' lemon, 'Cravo Santa Cruz Rangpur' lime, hybrid LVK x LCR - 010 and 'Sunki Tropical' mandarin. Yield efficiency was not influenced by the rootstocks. Both rootstocks 'Red Rough' lemon and 'Cravo Santa Cruz Rangpur' lime provide more regularity to 'Pineapple' sweet orange in Bahia and Sergipe groves.

Regarding plant resistance, the rootstocks did not influence the population densities of mites $P$. oleivora, $E$. banksi and $T$. mexicanus on 'Pineapple' sweet orange.

Rootstocks that promote bigger fruits, both in relation to mass and diameter, also induced thicker peels, lower juice contents and total soluble solids per box.

'Red Rough' lemon and 'Orlando' tangelo presented lower total soluble solids content. Ascorbic acid contents were closely related to total soluble solids.

The physical and chemical quality of fruits from the 'Pineapple' sweet orange is influenced by the rootstocks and meets the requirements of the juice industry.

RESUMO: O objetivo deste trabalho foi avaliar o desempenho agronômico da laranjeira 'Pineapple' em combinação com dez porta-enxertos, nas safras 2011-2017, com vistas à recomendação das melhores combinações para exploração comercial na região citrícola dos estados da Bahia e de Sergipe. O experimento consistiu de laranja doce 'pineapple' enxertado nos porta-enxertos limoeiros 'Cravo Santa Cruz', limoeiro 'Rugoso Vermelho', tangeleiro Orlando, tangerineira 'Sunki' Tropical, citrumelo 'Swingle', citrandarins 'Indio', 'Riverside', além dos híbridos HTR - 051 e LVK x LCR - 010 e 'TSKC x CTTR - 002'. O trabalho foi instalado em 2008, no município de Umbaúba, em Sergipe, no delineamento experimental de blocos ao acaso, com quatro repetições, duas plantas por parcela, no espaçamento de $6 \mathrm{~m} \times 4 \mathrm{~m}$, correspondendo a uma população de 416 plantas $\cdot$ ha $^{-1}$, com manejo em sistema de produção convencional, sem o uso de irrigação. Os seguintes parâmetros agronômicos foram avaliados: crescimento vegetativo, tolerância à seca, produção e qualidade físico-química de frutos, além da abundância de ácaros fitófagos. Os híbridos LVK x LCR - 010 e TSKC x CTTR - 002, assim como o limoeiro 'Cravo Santa Cruz', conferiram um maior nível de tolerância ao período seco, em contraste com maior suscetibilidade à seca relacionada ao tangelo 'Orlando' e ao citrumelo 'Swingle'. Os porta-enxertos HTR - 051, citrandarin 'Riversidade', citrumelo 'Swingle' e TSKC x CTTR - 002 induziram menor porte às plantas, demonstrando aptidão ao adensamento de plantio. A produção acumulada da laranjeira 'Pineapple' foi maior sobre os porta-enxertos limoeiros 'Rugoso Vermelho' e 'Cravo Santa Cruz', híbrido LVK x LCR - 010 e tangerineira 'Sunki Tropical'. A eficiência produtiva não foi influenciada pelos porta-enxertos. A qualidade física e química de frutos da laranjeira 'Pineapple' foi afetada pelos porta-enxertos e atendeu aos padrões exigidos pela indústria de sucos. Os porta-enxertos estudados não causaram variações nos níveis de populações dos ácaros Phyllocptruta oleivora, Eutetranychus banksi e Tetranychus mexicanus. Com base nos resultados conclui-se que os limoeiros 'Rugoso Vermelho' e 'Cravo Santa Cruz' determinam maior regularidade de produção de frutos à laranjeira 'Pineapple' nas regiões produtoras da Bahia e de Sergipe.

PALAVRAS-CHAVES: Citros. Eficiência produtiva. Ácaros fitófagos. Densidade de plantio.

\section{REFERENCES}

AULER, P. A. M.; FIDALSKI, J.; PAVAN, M. A.; NEVES, C. S. V. J. Produção de laranja 'Pêra' em sistemas de preparo do solo e manejo nas entrelinhas. Revista Brasileira de Ciência do Solo, Viçosa, v.32, n.1, p.363374, 2008. http://dx.doi.org/10.1590/S0100-06832008000100034 
AZEVEDO, F. A.; PACHECO, C. A.; SCHINOR, E. H.; CARVALHO, S. A.; CONCEIÇÃO, P. M.

Produtividade de laranjeira Folha Murcha enxertada em limoeiro Cravo sob adensamento de plantio. Bragantia, Campinas, v.74, n.2, p.184-188, 2015. http://dx.doi.org/10.1590/1678-4499.0374

AZEVEDO, F. A.; SCHINOR, E. H.; CONCEIÇÃO, P. M.; PACHECO, C. A.; DE NEGRI, J. D.; CRISTOFANI-YALY, M. Physicochemical quality of early-maturing 'Navel' sweet oranges. Semina:

Ciências Agrarias. Londrina, v. 38, n.1, p. 35-46, 2017. http://dx.doi.org/10.5433/1679-0359.2017v38n1p35

BACAR, E. L. C. Desempenho da laranjeira 'Jaffa' enxertada sobre cinco porta-enxertos em Londrina, PR. 2014. 54 p. Dissertação de Mestrado- Universidade Estadual de Londrina, Londrina. 2014.

BARBASSO, D. V.; PIO, R. M.; CARVALHO, S. A. Compatibilidade de variedades híbridos de tangerinas enxertadas sobre citrumelo 'Swingle'. Laranja, Cordeirópolis, v. 26, n. 1, p. 59-67, 2005.

BASTOS, D. C.; FERREIRA, E. A.; PASSOS, O. S.; SÁ, J. F. de; ATAÍDE, E. M.; CALGARO, M. Cultivares copa e porta-enxertos para a citricultura brasileira. Informe Agropecuário, Belo Horizonte, v.35, n.281, p.3645, 2014.

BASTIANEL, M.; SIMONETTI, L. M.; SCHINOR, E. H.; GIORGI, R.O.; NEGRI, J. D. de; GOMES, D.N.; AZEVEDO, F.A. Avaliação do banco de germoplasma de mexericas com relação às características físicoquímicas e suscetibilidade à mancha marrom de alternária. Bragantia, Campinas, v. 73, n. 1, p. 23-31, 2014. http://dx.doi.org/10.1590/brag.2014.004

BLUM, A. Effective use of water (EUW) and not water use efficiency (WUE) is the target of crop yield improvement under drought stress. Field Crops Research, v.112, p.119-123, 2009.

https://doi.org/10.1016/j.fcr.2009.03.009

BLUMER, S.; POMPEU JUNIOR, J. Avaliação de citrandarins e outros híbridos de trifoliata como portaenxertos para citros em São Paulo. Revista Brasileira de Fruticultura, Jaboticabal, v. 27, n. 2, p. 264-267, 2005. http://dx.doi.org/10.1590/S0100-29452005000200019

CANTUARIAS-AVILÉS, T.; MOURÃO FILHO, F. A. A.; STUCHI, E. S.; SILVA, S. R.; ESPINOZANUÑES, E. Horticultural Perfomace of 'Folha Murcha' Sweet Orange Onto Twelve Rootstocks. Scientia Horticulturae, Amsterdam, v. 129, n.2 p.259-265, 2011. https://doi.org/10.1016/j.scienta.2011.03.039

CAPUTO, M.M.; MOURÃO FILHO, F.A.A.; SILVA, S.R.; BREMER NETO, H.; COUTO, H.T.Z.; STUCHI, E.S. Seleção de cultivares de laranja doce de maturação precoce por índices de desempenho. Pesquisa Agropecuária Brasileira, Brasília, v. 47, p. 1669-1672, 2012. http://dx.doi.org/10.1590/S0100204X2012001100015.

CARVAlHO, H. W. L. de.; MARTINS, C. R.; TEODORO, A. V.; SOARES FILHO, W.dos S.; PASSOS, O. S. Agronomical perfrmance of 'Piemonte' mandarin grafted on several rootstocks in the Brazilian Coastal Tablelands. Pesquisa Agropecuária Brasileira, Brasília, v.51, n. 11, p. 1830-1838, $2016 \mathrm{a}$. http://dx.doi.org/10.1590/s0100-204x2016001100005

CARVALHO, L. M. de; H. W. L de C.; SOARES FILHO, W.; MARTINS, C.R.; PASSOS, O.S. Porta-enxertos promissores, alternativos ao limoeiro 'Cravo', nos Tabuleiros Costeiros de Sergipe. Pesquisa Agropecuária Brasileira, Brasília. v.51, n. 2, p. 132-141, 2016b. http://dx.doi.org/10.1590/S0100-204X2016000200005

CERQUEIRA E. C.; CASTRO NETO M. T.; PEIXOTO C. P.; SOARES FILHO W. S.; LEDO, C. A. S.; OLIVEIRA, J. G. Resposta de porta-enxertos de citros ao déficit hídrico. Revista Brasileira de Fruticultura. Jaboticabal, V. 26, p.515-519, 2004. http://dx.doi.org/10.1590/S0100-29452004000300034. 
CHACÓN, J. M.; ASPLEN, M. K.; HEIMPEL, G. E. Combined effects of host-plant resistance and intraguild predation on the soybean aphid parasitoid Binodoxys communis in the field. Biological Control, V. 60, n.1, p.16-25. 2012. http://dx.doi.org/10.1016/j.biocontrol.2011.09.003

CUNHA SOBRINHO, A. P. da; PASSOS, O.S.; SOARES FILHO, W.S. Cultivares porta-enxerto. In CUNHA SOBRINHO, A.P.; MAGALHÃES, A.F.J.; SOUZA, A.S; PASSOS, O.S.; SOARES FILHO, W.S. Cultura dos citros. Brasília, DF: Embrapa, 2013, v.1, p.233-292.

CURTOLO, M.; CRISTOFANI-YALY, M.; GAZAFFI, R.; TAKITA, M. A.; FIGUEIRA, A.; MACHADO, M. A. QTL mapping for fruit quality in Citrus using DArTseq markers. BMC Genomics, v 18, p.289-305, 2017. https://doi.org/10.1186/s12864-017-3629-2

DUARTE, T. F.; BRON, I. U.; RIBEIRO, R. V.; MACHADO, E. C.; MAZZAFERA, P.; SHIMIZU, M. M. Efeito da carga pendente na qualidade de frutos de laranjeira 'Valência'. Revista Brasileira de Fruticultura. Jaboticabal, v.33, p.823-829, 2011. http://dx.doi.org/10.1590/S0100-29452011005000098.

FIDALSKI, J.; SCAPIM, C. A.; STENZEL, N. M. C. Divergence of 'folha murcha' orange tree rootstocks as influenced by two groundcover crops. Revista Brasileira de Ciência do Solo, Viçosa, v.31, n.2, p.353-360, 2007. http://dx.doi.org/10.1590/S0100-06832007000200017.

FRANÇA, N. O., AMORIM, M. S., GIRARDI, E. A., PASSOS, O. S., SOARES FILHO, W. S. Performance of 'Tuxpan Valencia' sweet orange grafted onto 14 rootstocks in northern Bahia, Brazil. Revista Brasileira de Fruticultura, Jaboticabal, v. 38, n.4, pg.1-9. 2016. http://dx.doi.org/10.1590/0100-29452016684

GALLO, D., NAKANO, O.; SILVEIRA-NETO, S.; CARVALHO, R. P. L.; BAPTISTA, G. C.; BERTIFILHO, E.; PARRA, J. R. P.; ZUCCHI, R. A.; ALVES, S. B.; VENDRAMIM, J. D.; MARCHINI, L. C.; LOPES, J. R. S.; OMOTO, C. Entomologia Agrícola. FEALQ, Piracicaba: Casari \& R. Constantino (Eds.); 2002. 920.p.

GOIS, I. B.; BORÉM, A.; CRISTOFANI-YALY, M.; RESENDE, M. D. V.; AZEVEDO, C. F.; BASTIANEL, M.; NOVELLI, V. M.; MACHADO, M. A. Genome wide selection in Citrus breeding. Genetics and Molecular Research, v.15, n4, p.1-14. 2016. DOI http://dx.doi.org/10.4238/gmr15048863

IBGE. Instituto Brasileiro de Geografia e Estatística. 2017. Levantamento Sistemático da produção agrícola: março de 2017. Disponível em: htttp://www.sidra.ibge.gov.br. Acesso em 09 de março, 2018.

INSTITUTO ADOLFO LUTZ. Métodos físico-químicos para análise de alimentos. São Paulo: Instituto Adolfo Lutz, 2008. 1020p. Disponível em: http://www.ial.sp.gov.br/index.html. Acesso em: 25 dez. 2012.

MARTINS C. R.; TEODORO A. V.; CARVALHO, H. W. L. Citricultura no Estado de Sergipe. Citricultura Atual. v.103, p. 14-17, 2014.

MARTINS, C. R.; CARVALHO, H. W. L.; TEODORO, A. V.; SOARES FILHO, W. S.; PASSOS, O. S. Agronomical performance of citrus scion cultivars grafted on Rangpur lime in north-eastern Brazil. Australian Journal of Crop Science, Sydney, v.10, p.16-23, 2016.

MACHADO, M. A.; YALY-C. M.; BATIANEL, M. Melhoramento, genética e genômica de citros para resistência a doenças. Revista Brasileira de Fruticultura, Jaboticabal, v. 33, n.1, p.158-172. 2011. http://dx.doi.org/10.1590/S0100-29452011000500019.

MEDEIROS, R. C.; MUSSER, R. S.; SILVA, M. M.; SANTOS, J. P. O.; NASCIMENTO JUNIOR, I. R. Análise exploratória das características morfológicas e qualitativas de variedades de laranjeiras de mesa da coleção em Brejão - PE. Revista Brasileira de Fruticultura, Jaboticabal, v. 35, n. 2, p. 500-507, 2013. http://dx.doi.org/10.1590/S0100-29452013000200020. 
MELO FILHO, J. F.; CARVALHO, L. L.; SILVEIRA, D. C.; SACRAMENTO, J. A. A. S.; SILVEIRA, E. C. P. Quality index in a cohesive yellow latosol cultivated with citrus. Revista Brasileira de Fruticultura, Jaboticabal, v.31, p.1168-1177. 2009. http://dx.doi.org/10.1590/S0100-29452009000400034.

MENDONÇA, M. C.; SILVA, L. M. S. Pragas dos citros. In: Silva LMS, Mendonça MC (Eds.), Manual do manejador fitossanitário dos citros. Embrapa Tabuleiros Costeiros, Aracaju. p.19-41. 2009.

MORAES, G. J.; FLECHTMANN, C. H. W. Manual de acarologia: Acarologia básica e ácaros de plantas cultivadas no Brasil. Holos, Ribeirão Preto. 288 p., 2008.

NEGREIROS, J. R. S.; NETO, R. C.; MIQUELONI, D. P.; LESSA, L. S. Estimativa de repetibilidade para caracteres de qualidade de frutos de laranjeira-doce. Pesquisa Agropecuária Brasileira, Brasília, v. 49, n. 1, p. 40-48, 2014. http://dx.doi.org/10.1590/S0100-204X2014000100006

NÚÑEZ, E. E.; MOURÃO FILHO, F. A. A.; STUCHI, E. S. Desenvolvimento vegetativo, produção e qualidade de frutos da tangerina 'Fremont' sobre quatro porta-enxertos. Revista Brasileira de Fruticultura, Jaboticabal, v.29, p.308-312, 2007. http://dx.doi.org/10.1590/S0100-29452007000200023

PASSOS, O. S.; CUNHA SOBRINHO, A. P.; SOARES FILHO, W. S. Cultivares copa. In CUNHA SOBRINHO, A. P.; MAGALHÃES, A. F. J.; SOUZA, A. S; PASSOS, O. S.; SOARES FILHO, W. S. Cultura do citros. Brasília, DF: Embrapa, 2013. pg.293-319. 2013.

POMPEU JUNIOR, J.; BLUMER, S. Híbridos de trifoliata como porta-enxertos para a laranjeira Valência. Pesquisa Agropecuária Brasileira, Brasília, v.44, n.7, p.701- 705, 2009. http://dx.doi.org/10.1590/S0100204X2009000700008

POMPEU JUNIOR, J.; BLUMER, S. Citrandarins e outros híbridos de trifoliata como porta-enxertos para laranjeira Valência. Citrus Research \& Technology, Cordeirópolis, v. 32, n. 3, p. 133-138, 2011. https://doi.org/10.5935/2236-3122.20110016

POMPEU JUNIOR, J.; BLUMER, S. Híbridos de trifoliata como porta-enxertos para laranjeira Pêra. Pesquisa Agropecuária Tropical, v. 44, n. 1, 2014. http://dx.doi.org/10.1590/S1983-40632014000100007.

PROGRAMA BRASILEIRO PARA MODERNIZAÇÃO DA HORTICULTURA . CEAGESP - Companhia de Entrepostos e Armazéns Gerais de São Paulo. Normas de classificação de laranjas. São Paulo: CEAGESP, 2011. Disponível em http://www.ceagesp.gov.br/produtor/classif/fc_laranja. Acesso em 18 de março de 2018.

PRUDENTE, R. M.; SILVA, L. M. S.; CUNHA SOBRINHO, A. P. Comportamento da laranjeira 'Pêra' D6 sobre cinco porta-enxertos em ecossistema de tabuleiros costeiros, Umbaúba-SE. Revista Brasileira de Fruticultura, Jaboticabal, v.26, n.1, p. 110-112, 2004. http://dx.doi.org/10.1590/S0100-29452004000100030.

RAMOS, Y. C.; STUCHI, E. S.; GIRARDI, E. A.; LEÃO, H. C. de; GESTEIRA, A. da S.; PASSOS, O. S.; SOARES FILHO, W. dos S. Dwarfing rootstocks for 'Valencia' sweet orange. Acta Horticulturae, v.1065, p.351-354, 2015. https://doi.org/10.17660/ActaHortic.2015.1065.42

RODRIGUES, M. J. D. S.; OLIVEIRA, E. R. M. D.; GIRARDI, E. A., LEDO, C. A. D. S.; SOARES FILHO, W. D. S. Citrus nursery tree production using different scion and rootstock combinations in screen house. Revista Brasileira de Fruticultura, Jaboticabal, v.38, n.1, p.187-201, 2016. http://dx.doi.org/10.1590/0100$2945-284 / 14$

SALIBE, A. A.; TEÓFILO SOBRINHO, J.; MÜLLER, G. W. Sinopse de conhecimentos e pesquisas sobre a laranja-'Pera'. Laranja, Cordeirópolis, v. 23, n. 1, p. 221-230, 2002.

SOBRINHO, A. P. C; PASSOS O. S.; SOARES, W. S. S. Cultivares. In: MAGALHÃES, A.F.J. (Ed.). Cultivo de citros. Cruz das Almas: Embrapa Mandioca e Fruticultura Tropical, 2004. p.36-43. 2004 
SOUZA, L. D.; SOUZA, L. DA S.; LEDO, C. A. DA S. Sistema radicular dos citros em Neossolo Quartzarênico dos tabuleiros costeiros sob irrigação e sequeiro. Pesquisa Agropecuária Brasileira, Brasília, v.42, p.1373-1381, 2007. http://dx.doi.org/10.1590/S0100-204X2007001000002.

SILVA, R. R.; TEODORO, A. V.; MARTINS, C. R.; CARVALHO, H. W. L.; SILVA, S. S.; FARIAS, A. P.; GUZZO, E. C. Seasonal variation of pest mite populations in relation to citrus scion cultivars in northeastern Brazil. Acta Agronomica, Bogotá, v.66, p. 90-295, 2017. https://doi.org/10.15446/acag.v66n2.55041

STENZEL, N. M. C.; NEVES, C. S. V. J.; MARUR, C. J.; GOMES J. C. Crescimento vegetativo de plantas cítricas no norte e noroeste do Paraná. Revista Brasileira de Fruticultura, Jaboticabal, v.27, p.412-417. 2005. http://dx.doi.org/10.1590/S0100-29452005000300018.

STUCHI, E. S.; DONADIO, L. C.; SEMPIONATO, O. R. Qualidade industrial e produção de frutos de laranjeira 'Valência' enxertada sobre sete portas-enxerto. Laranja, Cordeirópolis. b23, n.2, p.453-471, 2002.

STUCHI, E. S.; ESPINOZA-NÚÑEZ, E.; MOURÃO FILHO, F. de A. A.; ORTEGA, E. M. M. Vigor, produtividade e qualidade de frutos de quatro tangerineiras e híbridos sobre quatro porta-enxertos. Revista Brasileira de Fruticultura. Jaboticabal, v.30, p.741-747, 2008. http://dx.doi.org/10.1590/S010029452008000300030.

VENDRAMIM, J. D., GUZZO, E. C. Plant resistance and insect bioecology and nutrition. In: PANIZZI AR, PARRA JRP (Eds.). Insect bioecology and nutrition for integrated pest management. CRC Press, Boca Raton. p.657-685, 2011. https://doi.org/10.1201/b11713-30 